\title{
Comparison of survival results of patients with T0 and T1-2-3 in pathological T staging in patients with non-small cell lung cancer who underwent surgery after neoadjuvant treatment
}

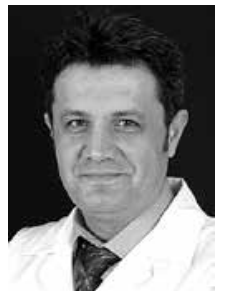

\author{
Tayfun Kermenli ${ }^{1}$, Hüseyin Melek ${ }^{2}$, Ahmet Sami Bayram², Cengiz Gebitekin² \\ ${ }^{1}$ Thoracic Surgery Clinic, Medicalpark Elazı ̆̆ Hospital, Elazı̆̆, Turkey \\ ${ }^{2}$ Department of Thoracic Surgery, School of Medicine, Uludağ University, Uludağ, Turkey
}

Kardiochir Torakochir Pol 2020; 17 (2): 47-51

\begin{abstract}
Aim: In this study, we aimed to compare the survival results of patients who underwent neoadjuvant treatment with NSCLC between March 1997 and August 2014 and were found to have TONO and T1-2-3/NO.

Material and methods: A hundred ninety-five patients who had complete neoadjuvant therapy, complete lung resection and lymph node dissection, and pathologically diagnosed as TO or T1-2-3/NO, MO were included in the study.

Results: Of the 195 patients included in the study, 181 were male, 14 were female and the mean age of the patients was 57.9. The mean age of the groups was as follows: group 1: 58.1, group 2: 57.7, group 3: 59.7 and group 4: 56.8 . In our series the most common complication was atelectasis $(n=19)$. Others were prolonged air leak $(n=16)$, pneumonia $(n=12)$, apical pleural space $(n=6)$, wound infection $(n=3)$, cardiac problems $(n=3)$, hematoma $(n=3)$, bronchopleural fistula $(n=3)$, empyema $(n=2)$, chylothorax $(n=1)$. The 5 -year survival rate for patients in the TONO group was $76.3 \%$. This rate was $71.8 \%$ in group 2, 63.6\% in group 3 and $44.1 \%$ in group 4.

Conclusions: Survival was found to be better in patients who underwent surgery after neoadjuvant therapy and had a complete pathological response. We believe that we can provide better results with the increase in the number of cases detected as TxNO after the neoadjuvant treatment and prolongation of the follow-up period.
\end{abstract}

Key words: non-small cell lung cancer, neoadjuvant treatment.

\section{Introduction}

In non-small cell lung cancer (NSCLC), the first choice of treatment is surgery $[1,2]$. Nowadays, despite the increase in the number of patients undergoing surgery with advances in early diagnosis and surgical methods, this rate

\section{Streszczenie}

Cel pracy: W badaniu porównano wyniki długości życia pacjentów poddanych od marca 1997 r. do sierpnia 2014 r. leczeniu neoadiuwantowemu niedrobnokomórkowego raka płuc (NSCLC), u których ustalono rozpoznanie patologiczne TONO i T1-2-3/NO. Materiat i metody: Do badania włączono 195 pacjentów, u których zastosowano leczenie neoadiuwantowe, wykonano doszczętną resekcję płuca i wycięto węzły chłonne oraz ustalono rozpoznanie patologiczne T0 lub T1-2-3/NO, MO.

Wyniki: W badaniu wzięło udział 195 pacjentów - 181 mężczyzn i 14 kobiet. Średni wiek pacjentów wynosił 57,9 roku. Średni wiek w poszczególnych grupach kształtował się następująco: grupa 1. - 58,1 roku, grupa 2. - 57,7 roku, grupa 3. - 59,7 roku, grupa 4. - 56,8 roku. W analizowanej grupie pacjentów najczęstszym powikłaniem była niedodma $(n=19)$. Wśród innych powikłań stwierdzono: długotrwały wyciek powietrza $(n=16)$, zapalenie płuc $(n=12)$, zgrubienie opłucnej szczytowej $(n=6)$, zakażenie rany $(n=3)$, zaburzenia kardiologiczne $(n=3)$, krwiak $(n=3)$, przetokę oskrzelowo-opłucnową $(n=3)$, ropniak $(n=2)$, chylothorax $(n=1)$. Wskaźnik przeżycia 5-letniego pacjentów z grupy TONO wyniósł 76,3\%. W grupie 2. wartość wskaźnika wyniosła 71,8\%, w grupie 3. - 63,6\%, a w grupie 4. - 44,1\%.

Wnioski: Wykazano, że dłużej żyli pacjenci poddani leczeniu chirurgicznemu po terapii neoadiuwantowej, u których uzyskano całkowitą odpowiedź patologiczną. Uważamy, że przy większej liczbie przypadków z rozpoznaniem TxN0 po leczeniu neoadiuwantowym i wydłużeniu okresu obserwacji uzyskane wyniki byłyby korzystniejsze.

Słowa kluczowe: niedrobnokomórkowy rak płuca, leczenie neoadiuwantowe.

is still $15-25 \%[3,4]$. The most important factor in achieving the desired success with surgical treatment is to perform a radical and complete resection at the earliest possible stage [5]. In this way, a high survival rate can be provided

Address for correspondence: Tayfun Kermenli MD, Thoracic Surgery Clinic, Medicalpark Elazığ Hospital, Elazığ, Turkey, phone: +90 4242348000, e-mail: tayfunkermenli@gmail.com

Received: 19.12.2019, accepted: 28.03.2020. 
to the patients by surgical intervention in NSCLC. However, there is still no consensus on optimal treatment in patients with locally advanced disease [6].

It has been shown that direct surgical treatment does not contribute to survival in patients with mediastinal lymph node metastasis in the preoperative period. Neoadjuvant treatment has been reported to be more beneficial in this patient group [7]. Therefore, patients with NSCLC may become eligible for surgery with chemotherapy, radiotherapy, or combined therapy as neoadjuvant treatment [8].

\section{Aim}

Prognosis is expected to be better in patients diagnosed with non-small cell lung cancer, who underwent surgery after neoadjuvant therapy and showed complete response in pathological T staging. In this study, we aimed to compare the survival results of patients who underwent surgical resection after neoadjuvant treatment and who had a complete pathological response in T staging (TONO) and those diagnosed as T1-2-3/NO.

\section{Material and methods}

Between March 1997 and August 2014, the records of 341 patients who were diagnosed with NSCLC, who underwent lung resection and mediastinal lymph node dissection following oncological treatment, were reviewed retrospectively. 195 patients who had complete neoadjuvant therapy, anatomical lung resection and mediastinal lymph node dissection, and pathologically diagnosed as TO or T1-2-3/N0, MO, were included in the study. The patients were directed to neoadjuvant therapy because they had local advanced lung cancer, mediastinal lymph node positivity, or surgically required pneumonectomy.

Patients with incomplete or wedge resection, remaining in exploration, patients with distant metastasis (brain, surrenal, etc.) or lymph node positivity, bilateral synchronous tumor or second mass in the same lung, or different organ malignancies were excluded from the study.

Thoracic computed tomography (CT), positron emission tomography (PET-CT), mediastinoscopy or mediastinotomy was performed before and after neoadjuvant treatment. PET restaging was not performed in patients receiving RT. These techniques were not used in staging since there was no endobronchial ultrasound bronchoscopy or endoscopic ultrasound in our hospital. Postoperative histopathologic (pTNM) staging was performed according to the TNM-8 staging system, which was renewed in 2009. Since the staging system changed in 2009, the results of patients prior to this date were reassessed and patients were staged according to TNM8. Histopathological typing was determined according to the classification that the World Health Organization renewed in 2011.

The records of the patients were scanned from the Avicenna program database and resection files of our clinic. The patients who were not in our follow-up were reached with their registered phone numbers. Death and survival were determined by entering the patients' ID numbers in the social security institution database.

After surgical treatment, pathologic examination revealed TONO (group 1): 47 patients, T1NO (group 2); 48, T2NO (group 3); 58 and T3NO (group 4); four separate groups consisting of 42 patients were formed.

\section{Statistical analysis}

Descriptive statistics were used for demographic and clinical characteristics of the patients. The $\chi^{2}$ test was used to compare the proportions between the groups. KaplanMeier analysis was performed to investigate the effect of predefined factors on survival. Survival of different groups was compared using the log-rank test. Cox regression analysis was used for multivariate analysis of factors related to survival. Statistical analyses were performed with SPSS software version 22.0 (SPSS Inc, Chicago, IL) and the statistical significance limit was set at $p<0.05$.

\section{Results}

Of the 195 patients included in the study, 181 (92.8\%) were male, $14(7.2 \%)$ were female and the mean age of the patients was 57.9 (38-85). The mean age of the groups was as follows: group 1: $58.1 \pm 6.73$, group 2: $57.7 \pm 8.34$, group 3 : $59.7 \pm 8.93$ and group 4: $56.8 \pm 7.5$. There was no statistically significant difference between the groups in terms of age distribution ( $p=0.64)$.

In the neoadjuvant treatment, 106 (54.4\%) of the 195 patients had chemotherapy and 89 (45.6\%) had chemo-radiotherapy. Radiotherapy was treated with 65 Gy in 54 patients and $45 \mathrm{~Gy}$ in 35 patients. Since our study was not a randomized controlled study, the chemotherapy protocols of the patients were not based on a certain order. In our clinic, interim evaluations are made routinely after 3 cycles of chemotherapy and whether the tumor is suitable for surgical resection is evaluated. However, 1 or 2 cycles of chemotherapy were given as an extra in patients who could not be given an appointment date for the surgery due to the density in our clinic. Neoadjuvant chemotherapy dose: 23 (11.82\%) patients had 2 cycles, 72 (37\%) had 3 cycles, 57 (29.2\%) had 4 cycles, 10 (5\%) had 5 cycles and 33 (17\%) had 6 cycles. Type of lung resection: lobectomy in 129 (66.2\%), bilobectomy in $21(10.8 \%)$, pneumonectomy in $27(13.8 \%)$ and segmentectomy in 18 (9.2\%).

After postoperative pathologic staging, TONO (group 1) in 47 (24.1\%) cases, T1N0 (group 2) in 48 (24.6\%); T2NO (group $3)$ in $58(29.7 \%)$ and T3NO (group 4) in $42(21.5 \%)$ cases were detected. In terms of histological subtypes, squamous cell carcinoma $(115 ; 58.9 \%)$ was the most frequently detected cell type. There was adenocarcinoma in 68 (34.9\%), large cell carcinoma in 6 (3.1\%) and unclassified in 6 (3.1\%) cases. Postoperative adjuvant chemotherapy was not given in patients with pathological TONO. Adjuvant therapy was completed in patients who did not receive a full dose of neoadjuvant chemotherapy and had no TONO in postoperative staging. The most common type of resection was lobectomy in all groups. Resection patterns and rates accord- 
Table I. Distribution of groups (demographic information, cell type, treatment type, type of resection, survival time

\begin{tabular}{|c|c|c|c|c|c|c|c|c|}
\hline \multicolumn{2}{|l|}{ Parameter } & \multirow{2}{*}{$\begin{array}{c}\text { Group } 1 \\
(n=47) \\
57.7\end{array}$} & \multirow{2}{*}{$\begin{array}{c}\text { Group } 2 \\
(n=48) \\
57.9\end{array}$} & \multirow{2}{*}{$\begin{array}{c}\text { Group } 3 \\
(n=58) \\
59.7\end{array}$} & \multirow{2}{*}{$\begin{array}{c}\text { Group } 4 \\
(n=42) \\
56.4\end{array}$} & \multicolumn{2}{|c|}{$\begin{array}{c}\text { Total } \\
(n=195)\end{array}$} & \multirow{2}{*}{$\begin{array}{c}P \text {-value } \\
0.64\end{array}$} \\
\hline Age & & & & & & 57.9 & & \\
\hline \multirow[t]{2}{*}{ Gender } & Male & 43 & 47 & 55 & 36 & 181 & $92.8 \%$ & \multirow[t]{2}{*}{0.886} \\
\hline & Female & 4 & 1 & 3 & 6 & 14 & $7.2 \%$ & \\
\hline \multirow[t]{4}{*}{ Pathologic cell types } & Squamous cell carcinoma & 32 & 27 & 30 & 26 & 115 & $58.9 \%$ & \multirow[t]{4}{*}{0.378} \\
\hline & Adenocarcinoma & 15 & 16 & 22 & 15 & 68 & $34.9 \%$ & \\
\hline & Large cell & - & 2 & 3 & 1 & 6 & $3.1 \%$ & \\
\hline & Others & - & 3 & 3 & - & 6 & $3.1 \%$ & \\
\hline \multirow{2}{*}{$\begin{array}{l}\text { Neoadjuvant } \\
\text { treatments }\end{array}$} & Chemotherapy & 16 & 28 & 34 & 28 & 106 & $54.4 \%$ & \multirow[t]{2}{*}{0.342} \\
\hline & Chemo-radiotherapy & 31 & 20 & 24 & 14 & 89 & $45.6 \%$ & \\
\hline \multirow[t]{4}{*}{ Resection types } & Lobectomy & 32 & 36 & 39 & 22 & 129 & 66.2 & \multirow[t]{4}{*}{0.138} \\
\hline & Bilobectomy & 5 & 5 & 9 & 2 & 21 & 10.8 & \\
\hline & Pneumonectomy & 8 & 2 & 6 & 11 & 27 & 13.8 & \\
\hline & Segmentectomy & 2 & 5 & 4 & 7 & 18 & 9.2 & \\
\hline Survival & & $76 \%$ & $71 \%$ & $63 \%$ & $44 \%$ & & $64 \%$ & \\
\hline
\end{tabular}

ing to stages occurred as given in Table I. Surgical resection was performed by thoracotomy in all patients. Neoadjuvant chemotherapy or chemo-radiotherapy, surgical treatment, age, sex, tumor cell type were not significantly associated with survival (Table I)

Sixty-eight (34.8\%) of our patients developed early postoperative complications; the most common complication was atelectasis ( $n=19,28 \%)$. Others were prolonged air leak ( $n=16,23.5 \%)$, pneumonia ( $n=12,17.6 \%)$, apical pleural space ( $n=6,8.9 \%)$, wound infection ( $n=3,4.4 \%)$, cardiac problems $(n=3,4.4 \%)$, hematoma $(n=3,4.4 \%)$, bronchopleural fistula ( $n=3,4.4 \%)$, empyema $(n=2,3 \%)$, chylothorax ( $n=1,1.4 \%$ ). One patient died due to respiratory failure and 1 patient died due to myocardial infarction and cardiac arrest. Early postoperative complications are shown in Table II. The incidence of complications was higher in patients receiving RT, but it was not statistically significant ( $p=0.237)$. There was no significant relationship between complications and survival ( $p=0.169)$.

Brain $(n=8,23.5 \%)$ and gastrointestinal system (GIS) ( $n=8,23.5 \%$ ) metastases were the most common during the follow-up. Others were bone $(n=7,20.6 \%)$, lung $(n=5$, $14.7 \%)$, multiorgan $(n=4,11.8 \%)$ and surrenal $(n=2,5.9 \%)$ (Table III).

The mean follow-up period was 52.7 months in group 1 , 51.2 months in group 2, 47 months in group 3 and 36.4 months in group 4 . The 5 -year survival rate for patients in the TON0 group was $76.3 \%$. This rate was $71.8 \%$ in group 2 , $63.6 \%$ in group 3 and $44.1 \%$ in group 4 . There was no significant difference in survival between group 1 and group 2 $(p=0.461)$. However, group 1 patients had significantly better survival than groups 3 and 4 , and this difference was statistically significant $(p<0.05)$ (Table IV).

\section{Discussion}

Several factors have been identified that may affect survival for patients receiving NSCLC. Although the stan-
Table II. Postoperative complications

\begin{tabular}{|c|c|c|c|}
\hline Complications & $\begin{array}{l}\text { Number of cases } \\
\qquad(n=68)\end{array}$ & Percentage & $P$-value \\
\hline Atelectasis & 19 & 28 & 0.169 \\
\hline Prolonged air leakage & 16 & 23.5 & \\
\hline Pneumonia & 12 & 17.6 & \\
\hline Apical pleural space & 6 & 8.9 & \\
\hline Wound infection & 3 & 4.4 & \\
\hline Cardiac problems & 3 & 4.4 & \\
\hline Bronchopleural fistula & 3 & 4.4 & \\
\hline Hematoma & 3 & 4.4 & \\
\hline Empyema & 2 & 3 & \\
\hline Chylothorax & 1 & 1.4 & \\
\hline
\end{tabular}

Table III. Distribution of distant metastases

\begin{tabular}{lcc} 
Metastasis localization & $\begin{array}{c}\text { Number of cases } \\
(n=34)\end{array}$ & Percentage \\
\hline Brain & 8 & 23.5 \\
\hline Liver & 8 & 23.5 \\
\hline Bone & 7 & 20.6 \\
\hline Lung & 5 & 14.7 \\
\hline Multiorgan & 4 & 11.8 \\
\hline Adrenal gland & 2 & 5.9 \\
\hline
\end{tabular}

Table IV. Number of patients, survival rate and $p$-value for comparison with TONOMO group according to pathological T staging

\begin{tabular}{lccc} 
Pathologic stage & $\begin{array}{c}\text { Number } \\
\text { of patients }\end{array}$ & $\begin{array}{c}\text { Survival } \\
\text { rate }(\%)\end{array}$ & P-value \\
TONOMO & 47 & 76.3 & - \\
\hline T1NOMO & 48 & 71.8 & 0.461 \\
\hline T2NOMO & 58 & 63.6 & 0.028 \\
\hline T3NOMO & 42 & 44.1 & 0.019 \\
\hline
\end{tabular}


dardization of the TNM staging system and histopathological typing have been tried to provide a standardization, the differences between the survival rates reveal the necessity of new studies. In our study, the survival was significantly better in the TONO and T1NO groups compared to the other groups, in parallel with the literature. The survival results of patients who had a complete pathological response after neoadjuvant treatment were better than other groups. There is also a significant difference between TONO patients with $\mathrm{T} 2$ and T3. Good survival results in group 1 may result from a complete response after neoadjuvant therapy in these patients. However, it is not possible to determine in which patient the complete pathological response will be obtained. This may be due to factors such as tumor differentiation. This shows us that we should work on this in the future.

In our series, lobectomy was the most preferred resection with 129 (66.2\%) patients. In the literature, it is recommended to perform lobectomy as the standard treatment approach especially in patients in the stage I groups $[9,10]$. The number of patients who underwent segmentectomy was 18 (9.2\%). According to our results, no statistically significant survival difference in terms of resection types indicates that segmentectomy may be preferred in appropriate patients. Osarogiagbon et al. stated that based on the data of 90 patients with Nx and 506 patients with NO, sublobar resections may be sufficient, although lobectomy is recommended in stage I patients [10].

Stefani et al. [11] reported that the results of segmentectomy with lymph node dissection in tumors smaller than $2 \mathrm{~cm}$ had similar results to lobectomy. Other publications that provide similar information suggest that segmentectomy may be sufficient if the tumor is limited in one segment [12]. Similar to the literature in our series, we preferred segmentectomy for tumors smaller than $2 \mathrm{~cm}$ limited to only one segment.

The standard surgical procedures to be performed in patients with stage II are lobectomy, bilobectomy or pneumonectomy, and mediastinal lymph node dissection [13]. In our series, pneumonectomy was performed in 27 (13.8\%) patients and bilobectomy was performed in 21 (10.8\%) patients. In T3NOMO cases, invaded tissues are resected en bloc and reconstruction is performed if necessary [14]. Sleeve resections with high complications for a long time nowadays, with low operative mortality, similar survival and increased quality of life, has become the standard surgical procedure in technically feasible patients, even with adequate pulmonary reserve $[15,16]$. Sleeve resection was performed in 18 (9.2\%) patients, of which 13 (6.6\%) were bronchial sleeve, 3 (1.5\%) arterial and bronchial sleeve, and 2 (1\%) were arterial sleeve resection. In our cases, surgical resection types were not significantly different in terms of survival. Storelli et al. [17] reported that sleeve resections can be safely performed after neoadjuvant treatment in 103 series. However, it is recommended to support the anastomosis line with a tissue flap. The 5 -year survival rate in NSCLC cases was 63\% [17].
Neoadjuvant therapies can achieve a high complete response rate. In the literature, pathological complete remission has been reported between $15 \%$ and $23 \%$ and survival time is prolonged in this patient group. It also increases the rate of tumor resectability [18]. In our study, the pathological complete response rate was found to be $16 \%$ in accordance with the literature and there was a significant improvement in survival in these patients.

In NSCLC stage IIIA-N2 disease, neoadjuvant chemotherapy or chemoradiotherapy allows complete resection of the tumor by regressing the stage and decreases the possibility of distant metastasis by providing systemic control in the early period $[19,20]$. However, a standard multimodal approach could not be defined in these patients. Neoadjuvant chemotherapy or chemoradiotherapy studies in this area are randomized trials of low-strength doublearm studies, usually involving single-arm phase II and a small number of patients. In our study, N2 was detected in 29 patients in preoperative staging with mediastinoscopy and mediastinotomy.

Side effects during the administration of combined modalities are known side effects of chemotherapy (bone marrow suppression, nausea-vomiting, nephrotoxicity, pulmonary toxicity, mucositis, hepatotoxicity, neurotoxicity, alopecia, etc.). In addition, there is additional surgical morbidity and mortality due to the development of pulmonary fibrosis after neoadjuvant chemotherapy. Surgical mortality rates between 0 and $9 \%$ have been reported in the studies [21, 22]. In our study, early postoperative mortality was $0.1 \%$.

Neoadjuvant radiotherapy increased the rate of complete pathological response (TONO). Although radiotherapy was given as a curative dose of approximately $60 \mathrm{~Gy}$ in the first years of our case series, the dose was changed to $45 \mathrm{~Gy}$ in the following years according to the literature and guidelines [23]. Although the rate of complication development was high in our patients receiving radiotherapy, there was no significant difference in survival.

Many studies and data report that there is no significant difference between histologic type and survival [24]. However, with the development of targeted chemotherapy protocols in cases with mutation, better results are obtained. In our series, no significant difference was found between survival and neoadjuvant chemotherapy treatments, chemotherapy + radiotherapy administration, age, sex, or tumor cell type.

In our case series, cisplatin was used most frequently as neoadjuvant chemotherapy; gemcitabine and paclitaxel were other options. We have never used targeted chemotherapy as a neoadjuvant therapy, but perhaps they may soon be used as a neoadjuvant therapy. There are several studies related to this, such as the work of Yashimo. In a study by Yashima et al. on 150 patients with NSCLC, the efficacy of targeted therapy was demonstrated [25]. The usability of these treatment options as a neoadjuvant chemotherapy protocol should be investigated. These studies show that targeted treatment options can be used as 
neoadjuvant treatment in NSCLC [26]. In this way, better survival times can be achieved.

\section{Conclusions}

Neoadjuvant therapy increases the chance of surgical treatment in NSCLC and this results in good survival. Patients with TONO have good survival, but it is unpredictable in which patients a full response is needed, and this is an area where further investigation is needed. It is clear that with the improvements in neoadjuvant chemotherapy and radiotherapy, we will get better survival results in NSCLC. Targeted therapies will also contribute to survival.

\section{Disclosure}

Authors report no conflict of interest.

\section{References}

1. Misiak P, Rzepkowska-Misiak B, Wcisło S, et al. Evaluation of the impact of radical tumor resection in lung cancer patients on the activity of selected antioxidant enzymes. Kardiochir Torakochir Pol 2014; 11: 414-420.

2. Dzięgielewski P, Kozłowski M, Nikliński J, et al. Assessment of epidemiological and clinical factors that can influence mediastinal metastatic disease in NSCLC patients qualified for surgical treatment. Kardiochir Torakochir Pol 2010; 7: 34-38.

3. Kowalewski J, Dancewicz M. NSCLC: lung resection in the pulmonary compromised patient. Kardiochir Torakochir Pol 2008; 5: 413-417.

4. Myrdal G, Gustafsson G, Lambe M, et al. Outcome after lung cancer surgery. Factors predicting early mortality and major morbidity. Eur J Cardiothorac Surg 2001; 20: 694-699.

5. Lee PC, Nasar A, Port JL, et al. Long-term survival after lobectomy for nonsmall cell lung cancer by video-assisted thoracic surgery versus thoracotomy. Ann Thorac Surg 2013; 96: 951-961.

6. Veeramachaneni NK, Feins RH, Stephenson BJ, et al. Management of stage IIIA non-small cell lung cancer by thoracic surgeons in North America. Ann Thorac Surg 2012; 94: 922-926.

7. Watanabe SI, Nakagawa K, Suzuki K, et al. Neoadjuvant and adjuvant therapy for Stage III non-small cell lung cancer. Lung Cancer Surgical Study Group (LCSSG) of the Japan Clinical Oncology Group (JCOG). Neoadjuvant and adjuvant therapy for stage III non-small cell lung cancer. Jpn J Clin Oncol 2017; 47: 1112-1118.

8. Song WA, Zhou NK, Wang W, et al. Survival benefit of neoadjuvant chemotherapy in non-small cell lung cancer: an updated meta-analysis of 13 randomized control trials. J Thorac Oncol 2010; 5: 510-516.

9. Bella MJ, Kowalewski J, Dancewicz M, et al. Lobectomy or wedge resection? The comparison of outcome in patients operated on for T1NOMO non-small cell lung cancer. Kardiochir Torakochir Pol 2008; 4: 397-401.
10. Osarogiagbon RU, Allen JW, Farooq A, et al. Outcome of surgical resection for pathologic NO and Nx non-small cell lung cancer. J Thorac Oncol 2010; 5: 191-196.

11. Stefani A, Nesci J, Casali C, Morandi U. Wedge resection versus lobectomy for T1N0 non-small cell lung cancer. Minerva Chir 2012; 67: 489-498.

12. Tieu BH, Sanborn RE, Thomas CR Jr. Neoadjuvant therapy for resectable nonsmall cell lung cancer with mediastinal lymph node involvement. Thorac Surg Clin 2008; 18: 403-415.

13. Wu HR, Liu CQ, Xu MQ, et al. Systematic mediastinal lymph node dissection outcomes and conversion rates of uniportal video-assisted thoracoscopic lobectomy for lung cancer. ANZ J Surg 2019; 89: 1056-1060.

14. Tomaszewski D, Dziedzic R, Rzyman W. Bronchial sleeve resection with complete pulmonary preservation. Kardiochir Torakochir Pol 2012; 9: 210-215.

15. Koike T, Yoshiya K, Tsuchida M, Toyabe S. Risk factor analysis of locoregional recurrence after sublobar resection in patients with clinicalstage IA nonsmall cell lung cancer. J Thorac Cardiovasc Surg 2013; 146: 372-378.

16. D’Andrilli A, Venuta F, Maurizi G, Rendina EA. bronchial and arterial sleeve resection after induction therapy for lung cancer. Thorac Surg Clin 2014; 24 411-421.

17. Storelli E, Tutic M, Kestenholz P, et al. Sleeve resections with unprotected bronchial anastomoses are safe even after neoadjuvant therapy. Eur J Cardiothorac Surg 2012; 42: 77-81.

18. Milleron B, Westeel V, Gounant V, et. al. Pathological complete response: a predictive survival factor after neoadjuvant chemotherapy in lung cancer. Bull Cancer 2016; 103: 66-72.

19. Gillaspie EA, Wigle DA. Management of stage IIIA (N2) non-small cell lung cancer. Thorac Surg Clin 2016; 26: 271-285.

20. Lei T, Xu XL, Chen W, et al. Adjuvant chemotherapy plus radiotherapy is superior to chemotherapy following surgical treatment of stage IIIA N2 non-smallcell lung cancer. Onco Targets Ther 2016; 9: 921-928.

21. Kernstine KH, Moon J, Kraut MJ, et al. Trimodality therapy for superior sulcus non-small cell lung cancer: Southwest Oncology Group-Intergroup Trial S0220. Ann Thorac Surg 2014; 98: 402-410.

22. Osarogiagbon RU, Ogbata O, Yu X. Number of lymph nodes associated with maximal reduction of long-term mortality risk in pathologic node-negative non-small cell lung cancer. Ann Thorac Surg 2014; 97: 385-393.

23. Albain KS, Swann S, Rusch VW, et al. Radiotherapy plus chemotherapy with or without surgical resection for stage III non-small-cell lung cancer: a phase III randomised controlled trial. Lancet 2009; 374: 379-386.

24. Jeon HW, Kim KS, Kim YD, et. al. Lymphatic vessel invasion in pathologic stage I and II non-small cell lung tumors. Surg Today 2015; 45: 1018-1024.

25. Yashima H, Shimizu K, Araki T, et al. Assessment of DDR2, BRAF, EGFR and KRAS mutations as therapeutic targets in non-adenocarcinoma lung cancer patients. Mol Clin Oncol 2014; 2: 714-718.

26. Zhong WZ, Chen KN, Chen C, et al. Erlotinib versus gemcitabine plus cisplatin as neoadjuvant treatment of stage IIIA-N2 EGFR-mutant non-small-cell lung cancer (EMERGING-CTONG 1103): a randomized phase II study. J Clin Oncol 2019; 37: 2235-2245. 